\title{
Estudo experimental comparativo da ação das neurocinas cardiotrofina-1 e oncostatina-m na regeneração nervosa periférica
}

\author{
Comparative experimental trial on cardiotrophin-1 and oncostatin-m activity in \\ the peripheral neve regeneration
}

Sérgio Augusto M. da Gama ; Rames Mattar JR. ${ }^{2}$; Ciro Ferreira da Silva 3 ; Raquel Dias Lainetti ${ }^{4}$

\section{RESUMO}

Os avanços das técnicas microcirúrgicas e o conhecimento detalhado do microambiente da regeneração podem contribuir significativamente na melhoria dos resultados das reparações nervosas periféricas. Nos últimos anos vários autores têm utilizado uma série de tecidos e substâncias interpostos entre os cotos de um nervo periférico seccionado, buscando estimular o crescimento axonal no local da lesão.

Através da técnica de tubulização, os autores estudam o efeito de duas neurocinas, a cardiotrofina-1 (CT-1) e a oncostatina-M (OsM), no crescimento axonal e na sobrevida dos neurônios sensitivos nos gânglios da raiz dorsal de L5, após a lesão de nervos ciáticos em camundongos C57BL/ $6 \mathrm{~J}$.

Utilizam 3 grupos de 7 animais que tiveram seus nervos seccionados e tubulizados com próteses de polietileno preenchidas com cardiotrofina-1, oncostatina-M e citocromo$\mathrm{C}$, associadas a um extrato de colágeno. Um quarto grupo de 3 animais, não operados, foi considerado por nós como grupo controle de normalidade.

Após 4 semanas da cirurgia, os camundongos foram sacrificados, e realizada a contagem das fibras mielínicas nos cabos de regeneração retirados. Os gânglios das raizes dorsais de L5 também foram dissecados possibilitando a contagem dos neurônios sensitivos.

Os dados foram analisados estatisticamente, permitindo concluir que as duas substâncias, utilizadas por nós, foram efetivas no estímulo ao brotamento axonal, porém, as mesmas não conseguiram impedir a morte dos neurônios sensitivos no gânglio da raiz dorsal de L5.

\section{SUMMARY}

The advances in microsurgery procedures and the detailed knowledge of regeneration may contribute significantly to the improvement of the results of peripheral nerve repair. In the last years, several authors have used series of tissues and substances interposed between the stumps of the sectioned peripheral nerve, trying to stimulate the axon growth in the lesion site.

Using the nerve entubulation technique, the author studied the effect of two neurokines, cardiotrophin-1 (CT-1) and oncostatin $M$ (OsM), in the axonal growth and in the survival rate of sensory neurons of $L-5$ root ganglion after sciatic nerve lesion in C57BL/6J mice.

The author used three groups of five animals that had their sciatic nerve sectioned and repaired with polyethylene tubular prostheses filled with cardiotrophin-1, oncostatin $-M$ or cytochrome- $C$, dissolved in the collagen extract.

The fourth group of three non-operated animals, were used the normal control group.

Four weeks after surgery, the mice were sacrificed. The myelinated axons of the removed regenerating nerve cable were counted. The L-5 dorsal root ganglions were also dissected to count sensory neurons.

Data were statistically analyzed, which allowed us conclude that both neurokines were effective in causing axonal sprouting, but they could not prevent sensory neuron death in L-5 dorsal root ganglion.

\footnotetext{
Trabalho realizado no IOT do HC-FMUSP e no ICB da USP.

1. Pós-graduando do IOT HC-FMUSP

2. Chefe do grupo de Cirurgia da Mão do IOT HC-FMUSP

3. Professor Titular do Departamento de Histologia ICB-USP

4. Pós-graduanda do ICB-USP.

This trial was performed at IOT, HC-FMUSP and at ICB-USP

1. Postgraduate at IOT HC-FMUSP

2. Chief of the Group of Hand Surgery of IOT HC-FMUSP

3. Titular Professor of Department of Histology ICB-USP

4. Postgraduate at ICB-USP 


\section{INTRODUÇÃO}

Permanece um grande desafio para médicos e pesquisadores, melhorar os resultados funcionais obtidos com as reparações nervosas.

Os recentes avanços, nas técnicas e no instrumental cirúrgico, trouxeram progressos que mudaram consideravelmente o prognóstico das lesões de nervos periféricos nas últimas décadas. Porém, não é possível ainda obter-se resultados uniformemente bons, a ponto de restaurar, por completo, a função de um nervo lesionado.

Desde a utilização da técnica microcirúrgica para a reparação de nervos periféricos por SMITH (1964) tem-se procurado novos métodos, menos agressivos, que evitem a sutura, mesmo com fios e agulhas apropriadas para a microcirurgia.

A técnica de tubulização para a reparação nervosa periférica, que consiste em posicionar os cotos de um nervo seccionado dentro de um tubo, permite analisar a ação de substâncias exógenas estimuladoras da regeneração entre as extremidades de um nervo seccionado, com pouca manipulação dos cotos.

Talvez a melhor compreensão do processo fisiológico da regeneração nervosa, através do estudo detalhado do seu "microambiente" e, principalmente sua regulação bioquímica, poderá trazer novas perspectivas.

A utilização de algumas substâncias que interferem na regeneração nervosa foi descrita por uma série de autores (MADISON et al., 1988; FIELDS et al., 1989; BAILEY et al., 1993; MUNSON et al., 1997; HO et al., 1998; SANTOS et al., 1999) e alguns benefícios estão bem estabelecidos, apesar de ainda não haver referências sobre o seu uso na prática clínica.

Dentre as neurocinas, que são substâncias com cadeia proteica característica, a cardiotrofina-1 (CT-1) e a oncostatinaM (OsM), ainda não foram suficientemente testadas, quanto à sua ação no processo de regeneração nervosa.

Atuando como cirurgião de mão e realizando cirurgias reconstrutivas de nervos periféricos, sentimo-nos estimulados a estudar a degeneração e regeneração nervosa e, particularmente, analisar o efeito das neurocinas na facilitação da regeneração nervosa.

Pretendemos, com este trabalho, estudar as ações das neurocinas cardiotrofina-1 (CT-1) e oncostatina-M (OsM) na regeneração de nervos ciáticos de camundongos C57BL/6J, seccionados e imediatamente reparados pela técnica da tubulização.

\section{MATERIAL E MÉTODO}

\section{1-Material}

O trabalho foi realizado com camundongos da linhagem C57BL/6J, machos e com a idade de 8 semanas na época da cirurgia. Utilizamos 15 animais, divididos em 3 grupos experimentais, de acordo com a substância utilizada no interior da prótese tubular e 1 grupo com 3 animais não operados, considerado por nós como padrão de normalidade.

\section{INTRODUCTION}

The improvement of functional results of nerve regeneration is a major challenge to physicians and researchers.

The new advances in surgical techniques and devices have considerably changed the prognostic of peripheral nerve lesions over the last decades. However, it is not possible to obtain satisfactory results like the complete regeneration of a lesioned nerve.

Since the use of the microsurgical technique for the peripheral nerve regeneration by SMITH (1964) new and less aggressive methods have been searched in order to avoid the suture, even if using adequate microsurgery needles and threads.

The entubulation technique for the peripheral nerve regeneration consists of positioning the stumps of a sectioned nerve inside a tube. This technique allows analyze the activity of exogenous substances, which stimulate the regeneration between the extremities of a sectioned nerve with little manipulation of the stumps.

The best understanding of the physiologic process and biochemical regulation of the nerve regeneration may bring forward new perspectives.

The use of some substances that interfere in the nerve regeneration was described by a number of authors (MADISON et al., 1988; FIELDS et al., 1989; BAILEY et al., 1993; MUNSON et al., 1997; HO et al., 1998; SAINTS et al., 1999). Some benefits are well established, although there are no references upon their utilization in the clinical practice.

Among neurokines, which are substances with a typical proteinic chain, the cardiotrophin-1 (CT-1) and the oncostatin-M (OsM) have not been sufficiently tested with relationship to their activity in the nerve regeneration process.

As a hand surgeon we perform peripheral nerve reconstruction surgeries, and we feel stimulated to study nerve degeneration and regeneration and analyze the neurokines activity in enhancing nerve regeneration.

The main objective of this trial is to study the activities of cardiotrophin-1 (CT-1) and oncostatin-M (OsM) in C57BL/6J mice sciatic nerve regeneration, which is sectioned and immediately repaired through the entubulation technique.

\section{MATERIAL AND METHOD}

\section{1- Material}

Fifteen male C57BL/6J mice, aged 8 weeks at the surgery were used. Animals were divided into 3 experimental groups in accordance with the substance utilized inside the tubular prosthesis. A group formed by 3 non-operated animals was considered as a control-group.

The humane and lyophilized CT-1 and OsM were obtained in Peprothec Company (USA). The cytochrome-c, a substance used as control in growth factor studies, was obtained in Sigma (USA).

All the substances above were given with an extract of collagen (Vitrogen, Collagen Corporation, Palo Alto, CA, USA). By 
A CT-1 e a OsM humanas e liofilizadas, foram adquiridas da empresa Peprothec (EUA). Já o citocromo-c, substância utilizada como controle em estudos de fatores de crescimento, foi obtido da Sigma (EUA).

Todas as substâncias acima foram administradas em associação com um extrato de colágeno (Vitrogen, Collagen Corporation, Palo Alto, CA, EUA), que ao transformar-se na sua forma gel, em contato com a temperatura do corpo do animal, impede o escoamento das substâncias colocadas no interior das próteses tubulares.

Dividimos os 3 grupos de 5 animais operados da seguinte forma: o primeiro teve suas próteses preenchidas com solução de colágeno e CT-1, o segundo com solução de colágeno e citocromo-c, e o terceiro de colágeno e OsM.

\section{2-Método}

\section{2 a-Técnica Cirúrgica:}

Os procedimentos cirúrgicos foram realizados com os animais sob anestesia geral com Avertin (500mg de tribromoetanol e 250mg de 2-metil-2-butanol, dissolvidos em 19,5 $\mathrm{ml}$ de água destilada) na dose de $0,02 \mathrm{ml} / \mathrm{g}$ de peso corporal intraperitoneal. Em seguida, eram tricotomizados na região de coxa esquerda e posicionados para a dissecção do nervo ciático. Sob visão microscópica (Zeiss OPM 240F), foi exposta a musculatura póstero lateral e o nervo ciático, através de incisão paralela ao fêmur (Fig. 1)

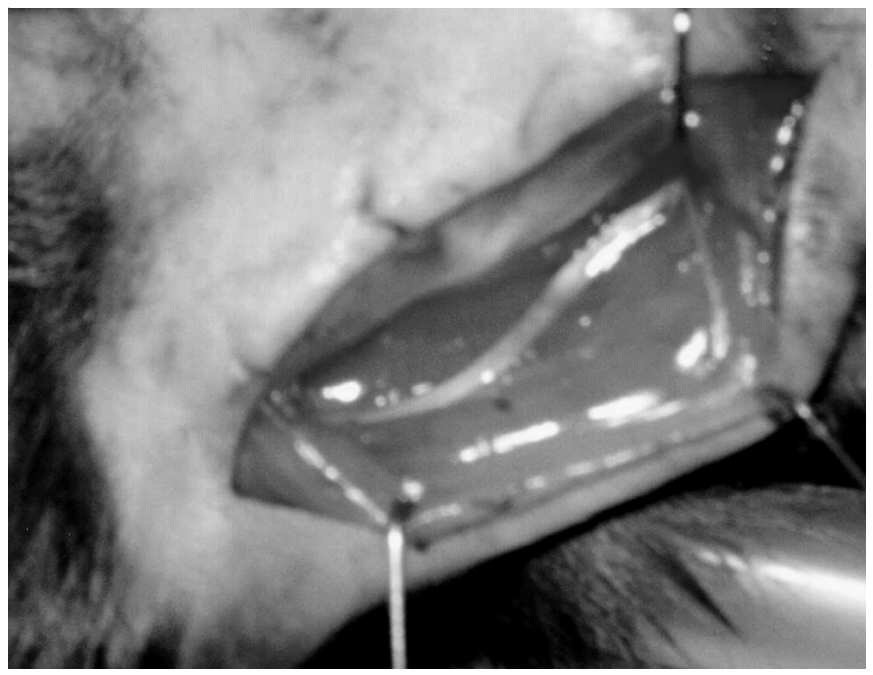

Fig. 1 - Exposição do nervo ciático

Fig. 1 - The sciatic nerve exposure

O nervo foi seccionado na região média da coxa, e os segmentos proximais e distais, após retrairem, foram fixados com um ponto único de sutura (monofilamento nylon 10-0 com agulha de $75 \mathrm{~mm}$, Ethicon) no interior de um tubo de polietileno de $6 \mathrm{~mm}$ de comprimento, $0,76 \mathrm{~mm}$ de diâmetro interno e 1,22 $\mathrm{mm}$ de diâmetro externo. A distância deixada entre os cotos nervosos foi de $4 \mathrm{~mm}$ (Fig. 2).

ACTA ORTOP BRAS 8(2) - ABR/JUN, 2000 contacting the animal body temperature, the extract of collagen becomes a gel, which avoid the leakage of the substances placed inside the tubular prostheses.

We divided the 3 groups composed of 5 operated animals as the following: the first group had its prostheses filled out with collagen solution plus CT-1, the second group, with collagen solution plus cytochrome-c, and the third group, with collagen plus OsM.

\section{2- Method}

2 a - Surgical technique

Surgical procedures were performed under general anesthesia using Avertin (tribromoethanol $500 \mathrm{mg}$ and 2-methyl-2-butanol $250 \mathrm{mg}$, plus distilled water $19.5 \mathrm{ml}$ ) at a dose of $0.02 \mathrm{ml} / \mathrm{g}$ which was given intraperitoneally. Then, mice left thigh were shaven and they were positioned for sciatic nerve dissection. Under microscopic vision (Zeiss OPM 240F) the posterolateral musculature and the sciatic nerve were exposed through an incision parallel to the femur (Figure 1).

The nerve was sectioned in the medium portion of the thigh. After the retraction of proximal and distal segments, they were fixated through a suture (mononylon 10-0 thread, a $75 \mathrm{~mm}$ needle - Ethicon) into a tube of polyethylene (6- $\mathrm{mm}$ length $\times 0.76-\mathrm{mm}$ internal diameter $\times 1.22-\mathrm{mm}$ external diameter). The distance between both nerve stumps was of $4 \mathrm{~mm}$ (Figure 2).

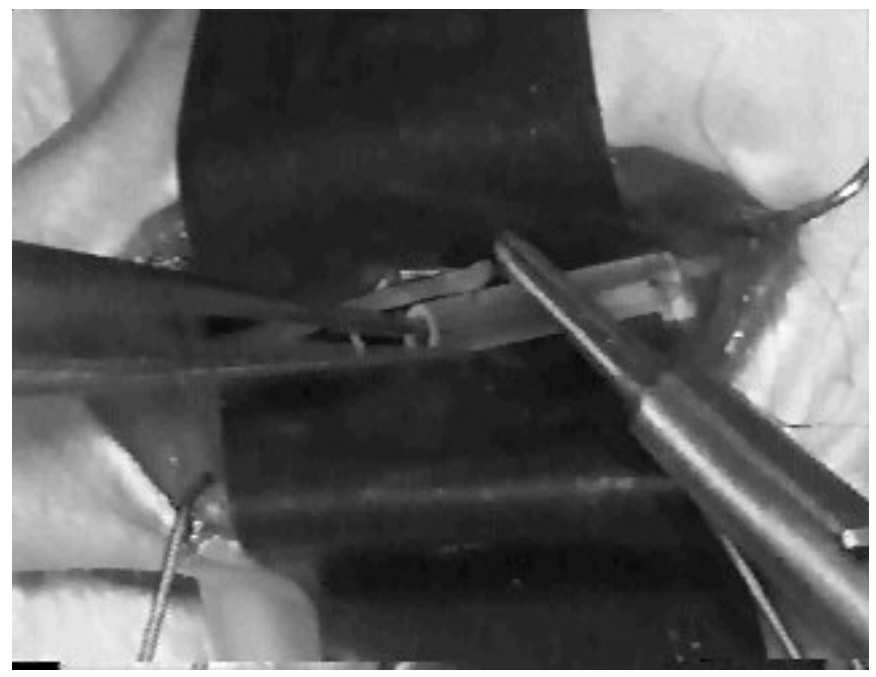

Fig. 2 - Nervo colocado no tubo

Fig. 2 - Nerve placed into the tube

Completions of prostheses with substances were done with the aid of a Hamilton syringe $(10 \mathrm{~m} /)$ and under microscopic vision in order to avoid air bubbles generation inside the prostheses (Figure 3). 
O preenchimento das próteses com as substâncias utilizadas, foi feito com o auxílio de uma micro seringa de Hamilton (10ml) e sob visão microscópica, para evitar a formação de bolhas de ar no interior das mesmas (Fig. 3).

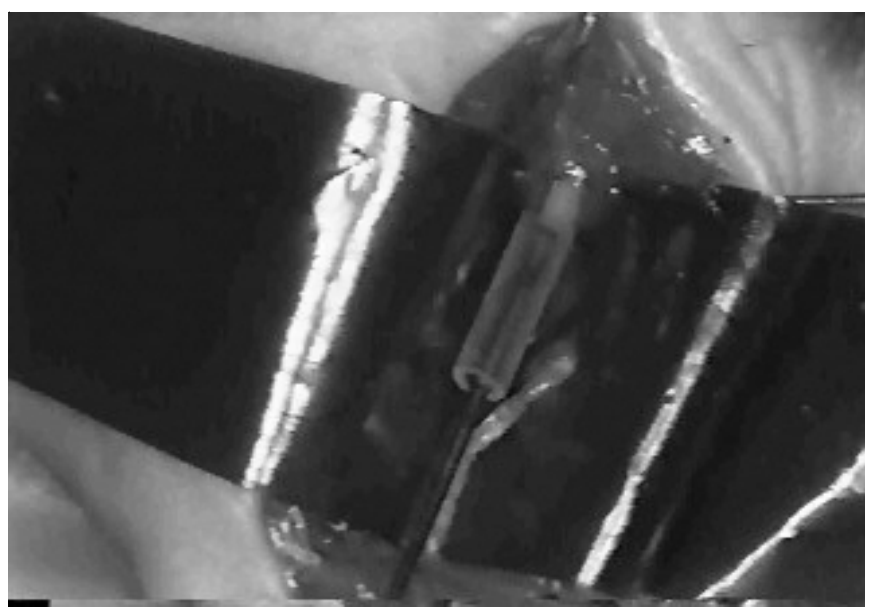

Fig. 3 - Preenchimento do tubo

Fig. 3 - Completion of the tube

As substâncias foram utilizadas à temperatura de aproximadamente $4^{\circ} \mathrm{C}$, ainda na forma líquida. Para evitarmos o extravasamento deste preparado, utilizamos vaselina na extremidade distal do tubo. Passados 20 minutos do implante, a solução introduzida sofria um processo de gelificação. A camada muscular foi suturada, e a pele fechada com grampos cirúrgicos de 7,5mm (Fig. 4).

\section{2b - Pós-operatório:}

$\mathrm{Na}$ sequência, os animais foram colocados em gaiolas individuais e mantidos em ciclo de 12 horas de claro-escuro durante todo período pós-operatório, e alimentação adequada.

\section{2c - Eutanásia e perfusão:}

Passadas 4 semanas, os animais foram anestesiados, procedeu-se a laparotomia através de incisão longitudinal com tesoura de iris e injetou-se 0,2 ml de uma solução de heparina (5000 Ul/ml) no baço (Fig. 5).
The substances were used in the liquid form about $4^{\circ} \mathrm{C}$ temperature. To avoid the leakage of this preparation, Vaseline was used in the distal extremity of the tube. After 20 minutes of the implant, the solution formed a gel. The muscular layer was sutured, and the skin was closed with the aid of 7.5- $\mathrm{mm}$ surgical staples (Figure 4).

\section{$2 b$ - Postoperative:}

Following this, animals were placed in individual cages where 12-hour alternating cycles (clear x darkness) occurred during every postoperative period, and under appropriate feeding.

\section{2c - Euthanasia and perfusion}

After 4 weeks, animals were anesthetized for the laparotomy, which was performed through a longitudinal incision made by iris scissors. A heparin solution 0.2- $\mathrm{ml}(5000 \mathrm{Ul} / \mathrm{ml})$ was injected in the spleen (Figure 5).

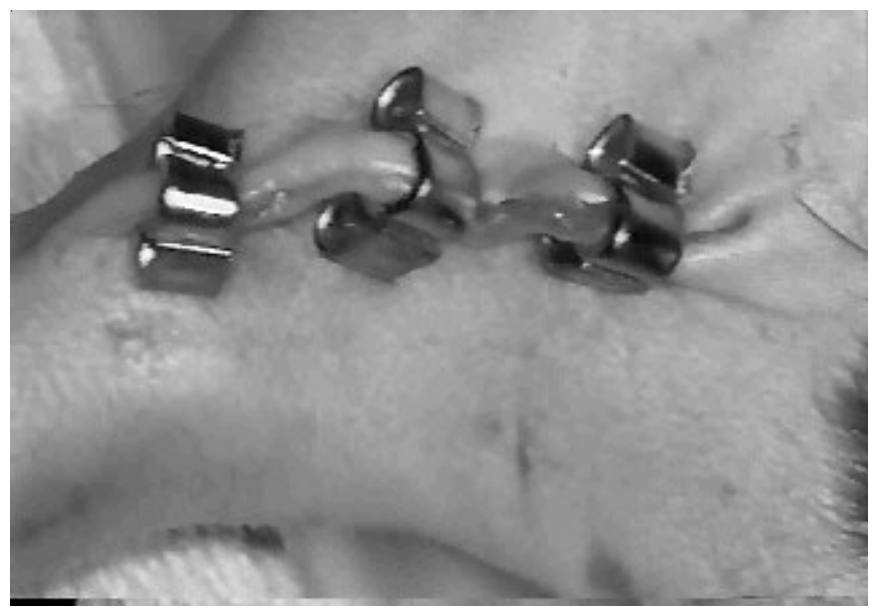

Fig. 4 - Fechamento da pele com grampos

Fig. 4 - Closing of the skin with surgical staples

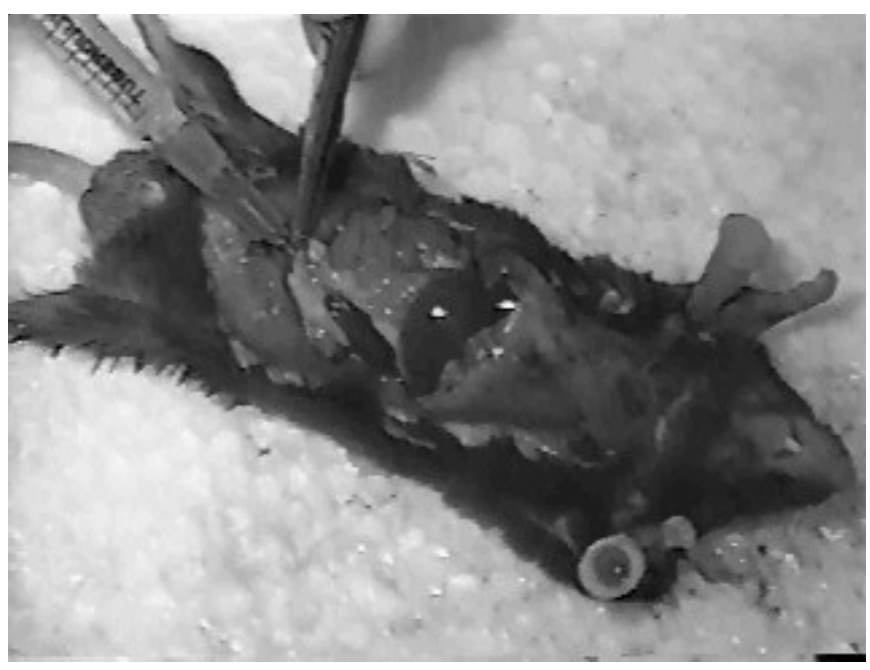

Fig. 5 - Abertura do abdomen e injeção de heparina

Fig. 5 - Opening of the abdomen and heparin injection 
2d- Análise histológica:

As próteses tubulares de polietileno com os segmentos nervosos regenerados, foram dissecadas e removidas, e colocadas na mesma solução fixadora a $4^{\circ} \mathrm{C}$ durante 1 dia. $\mathrm{O}$ material foi então pós-fixado em solução de tetróxido de ósmio (2\% em tampão de fosfato de sódio a 0,1 M e pH 7,3) durante 2 horas a $4^{\circ} \mathrm{C}$, e desidratado através de uma série crescente de álcool etílico, clareado em óxido de propileno e incluído em resina Epoxy. Foram feitos cortes transversais com $1 \mathrm{~mm}$ de espessura da parte média dos cabos regenerados, e corados com azul de toluidina $0,5 \%$.

Após o período de perfusão, a coluna vertebral dos animais era aberta para a retirada do gânglio espinhal de L5 que, em seguida, foi processado para inclusão em historesina, cortados seriadamente a $5 \mathrm{~mm}$ de espessura, corados com solução de azul de toluidina/fucsina. Através de um microscópio de luz (Zeiss) conectado a uma câmara clara, com aumento de objetiva de 25X, foram contados os corpos celulares dos neurônios sensitivos, presentes no gânglio de L5, e que apresentavam um nucléolo evidente. A contagem foi feita em 1 de cada 10 cortes da seriação.

As fibras mielínicas dos cabos regenerados, foram submetidas a uma análise quantitativa através de cortes semifinos de $1 \mathrm{~mm}$. Foi utilizado um microscópio de luz (Zeiss) conectado a uma câmara clara (Zeiss) e interligado a um microcomputador PC por um controlador de estágio. A interação com a imagem observada pelo operador foi feita através de uma mesa digitalizadora (Summagraphics) conectada ao microcomputador. Foi utilizado o programa CARP (Biographics Inc. EUA) baseado no sistema operacional UNIX.

Esta análise quantitativa seguiu as seguintes etapas: a) o sistema para análise das imagens foi calibrado de acordo com os diferentes aumentos das objetivas do microscópio; b) através de uma objetiva de baixo aumento, foram traçados os contornos dos cortes a serem estudados; c) o sistema dividia automaticamente os contornos em campos e armazenava na memória do computador; d) as fibras mielínicas foram marcadas pelo observador com o cursor da mesa digitalizadora através da câmara clara e da objetiva de 100X;

e) era sinalizado pelo operador, o término da marcação de todas as fibras de um determinado campo; f) ao completar o último campo, o computador fornecia a somatória das fibras marcadas, seguida da plotagem das mesmas na tela do monitor. Esse sistema evitou a contagem dupla de fibras presentes no campo observado.

\section{ANÁLISE ESTATÍSTICA}

A avaliação estatística dos dados quantitativos obtidos em cada uma das situações experimentais, foi realizada através do método de Newman-Keuls, com o auxílio do programa de computação "Primer of Biostatistics"(versão 1.0/ 1988).

O padrão de significância adotado foi de $p<0,05$. 2d - Histological analysis:

The polyethylene tubular prostheses with the regenerated nerve segments were dissected and removed and they were placed in the same solution of fixation about $4^{\circ} \mathrm{C}$ for 1 day. Then the material was post-fixed in osmium tetroxide solution (2\% sodium phosphate buffer $0.1 \mathrm{M}$ and $\mathrm{pH}$ 7.3) for 2 hours about $4^{\circ} \mathrm{C}$. It was dehydrated using ethyl alcohol, cleared up in propylene oxide and included in Epoxy resin. Traverse sections of 1- $\mathrm{mm}$ thickness were made of the medium part of the regenerate cables. Toluidine blue $0.5 \%$ was used to stain them.

After the perfusion period, the spinal cord of the animals was opened for removing the L-5 spinal ganglion. The ganglion was included in historesin, and serially cut in sections of $5 \mathrm{~mm}$ of thickness. Then it was stained through toluidine blue/fuchsin solution. Sensory neuron cell bodies of L-5 ganglion that had an apparent nucleolus were counted through a light microscope (Zeiss) $25 x$. The count was made in 1 among 10 cuts of the series.

The myelinated fibers of the regenerate cables underwent a quantitative analysis. Sections of $1 \mathrm{~mm}$ of thickness were analyzed through a light microscope (Zeiss), which was connected to a clear camera (Zeiss) and a PC. The interaction with the image observed by the operator was made through a digitized table (Summagraphics) connected to the computer. It was used the CARP program (Biographics Inc. USA) based on the operating system UNIX.

This quantitative analysis followed the following steps: a) the system used for analysis of the images was gauged according to the different increases of the microscope lenses. b) Using a lens of low increase, cut contours to be studied were traced. c) The system automatically divided the contours in fields and stored them in the computer memory. d) Using the cursor of the table through the clear camera and lens of 100X myelin fibers were marked by the observer. e) The operator signalized the end of the demarcation of all fibers of a certain field. f) When completing the last field, the computer made the sum of the marked fibers, followed by their plottage in the monitor screen. This system avoided the double count of fibers of the observed field.

\section{STATISTICAL ANALYSIS}

The statistical analysis of the quantitative data obtained from each one of the experimental situations was performed according to Newman-Keuls method, using a computer program named "Primer of Biostatistics" (version 1.0 / 1988).

The significance level was $p<0,05$. 


\section{RESULTADOS}

\section{DADOS QUALITATIVOS}

Após 4 semanas do implante das próteses tubulares, evidenciou-se em todos os animais uma estrutura com coloração leitosa, denominada cabo de regeneração (CR), com diâmetro decrescente de proximal para distal entre os cotos nervosos.

Em toda extensão do CR observou-se uma rede de vasos sanguíneos. Um líquido amarelado preenchia o espaço entre a superfície externa do CR e a parede interna da prótese tubular.

Cortes transversais da porção média dos CR, observados à microscopia de luz, mostraram que os animais que tiveram as próteses preenchidas com colágeno e CT-1 ou OsM apresentavam um diâmetro maior dos CR que os animais implantados com colágeno e citocromo-C. Através dos mesmos cortes, os CR apresentavam grupos de axônios organizados em minifascículos, característica do processo de compartimentalização, típico da regeneração nervosa periférica. Estes minifascículos eram envoltos por seu próprio perineuro, e vários destes conjuntos unidos por um epineuro.

Nos cortes transversais dos nervos ciáticos de animais não operados, foi possível distinguir os seus quatro fascículos que vão formar os nervos tibial, fibular, sural e ramo cutâneo.

\section{DADOS QUANTITATIVOS}

Após 4 semanas da tubulização, contamos o número total de fibras mielinizadas dos CR dos 3 grupos de animais operados e dos nervos ciáticos dos 3 camundongos não operados, e os dados obtidos encontram-se na Tabela 1 e Gráfico 1.

\section{RESULTS}

QUALITATIVE DATA

Four weeks after the tubular prostheses implant, a milky-white structure named regeneration cable (RC), with a proximal-distal decreasing diameter between nerve stumps, was noted in all animals.

In all the $R C$ extension a net of blood vessels was observed. A yellowish liquid filled out the space between the external surface of $R C$ and the internal wall of the tubular prosthesis.

Traverse sections of the $R C$ medium portion, which were observed to the light microscope, showed that animals that had the prostheses filled out with collagen and CT-1 or OsM presented a larger diameter of $R C$ than animals that were implanted with collagen and cytochrome-C. Through the same sections, $R C$ presented groups of axons organized in small fascicles, which is a characteristic of the compartment process, typical of the peripheral nerve regeneration. Their own perineurium surrounded these fascicles. Several of these united groups were surrounded for an epineurium.

In traverse sections of sciatic nerves of non-operated animals, it was possible to distinguish their four fascicles to form tibial, fibular, sural nerves and the cutaneous branch.

\section{QUANTITATIVE DATA}

After 4 weeks from entubulation, the total number of $R C$ myelinated fibers of the 3 groups of operated animals and the sciatic nerves of the 3 non-operated mice were counted and data obtained are in the Table 1 and Graph 1.

Table 1 - Number of myelinated axons in the regeneration cable in the groups of animals studied.

\begin{tabular}{ccccc}
\hline Animals & Cardiotrophin & Oncostatin & Cytochrome & Non-operated \\
\hline 1 & 1968 & 2040 & 1150 & 3311 \\
2 & 1877 & 1996 & 1302 & 3054 \\
3 & 2039 & 1932 & 1698 & 3407 \\
4 & 2192 & 1976 & 1639 & - \\
5 & 2124 & 2488 & 1456 & - \\
${ }^{*} M$ & 2040 & 2086 & 1449 & 3257 \\
${ }^{*} M S E$ & 56 & 102 & 102 & 49 \\
\hline
\end{tabular}

* $M=$ mean $/$ * MSE = mean standard error /

Table 2 - Number of cell bodies of sensory neurons in the L-5 dorsal root ganglion neuron in the animals tudied.

\begin{tabular}{ccccc}
\hline Animals & Cardiotrophin & Oncostatin & Cytochrome & non-operated \\
\hline 1 & 723 & 687 & 711 & 997 \\
2 & 567 & 705 & 688 & 1281 \\
3 & 619 & 685 & 633 & 1145 \\
4 & 588 & 703 & 642 & - \\
5 & 675 & 692 & 612 & - \\
${ }^{*} M$ & 634 & 694 & 657 & 1141 \\
${ }^{*} M S E$ & 29 & 4 & 18 & 64 \\
${ }^{*} M=$ mean / * MSE = mean standard error / & &
\end{tabular}


Graph 1 - Number of myelinated axons in the regeneration cable in the groups of animals studied.

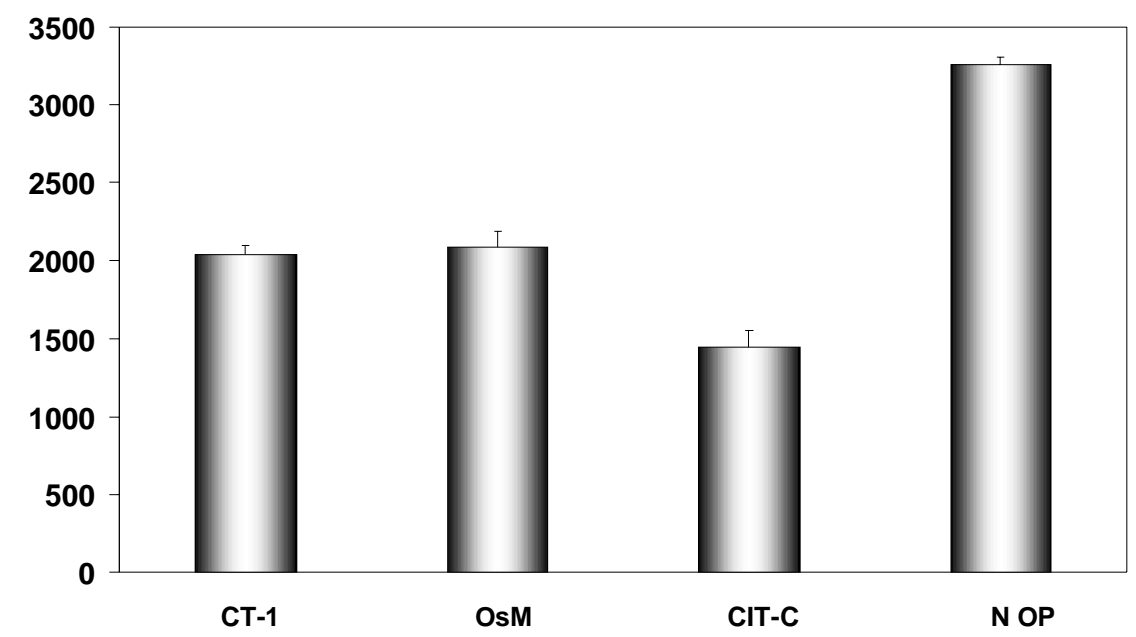

Comparando os grupos estudados através da análise estatística pelo método de Newman-Keuls, obtivemos o seguinte resultados: o número de axônios mielínicos nos $\mathrm{CR}$ dos animais implantados com colágeno e OsM (2086 \pm 102$)$ e colágeno e CT-1 (2040 \pm 56$)$, foi significativamente maior $(p<0,05)$ que nos grupos implantados com colágeno e citocromo-C (1449 \pm 102$)$, e significativamente menor $(p<0,05)$ que no grupo de animais não operados (3257 \pm 59$)$ Gráfico 1.

Após 4 semanas, o número de corpos celulares de neurônios sensitivos no gânglio da raíz dorsal de L5 contados nos animais operados e não operados, pode ser visto na Tabela 2 e Gráfico 2.
Results from statistical analysis by Newman-Keuls method showed that the number of myelinated axons in $R C$ of the animals who were implanted with collagen plus OsM (2086 \pm 102$)$ and collagen plus CT-1 (2040 \pm 56$)$ was significantly larger $(p<0.05)$ in comparison to animals implanted with collagen plus cytochrome-C $(1449 \pm 102)$. Otherwise, this number was significantly smaller $(p<0.05)$ in comparison to the group of nonoperated animals (3257 \pm 59$)$. Graph 1.

After 4 weeks, the number of cell bodies of sensory neurons in L-5 dorsal root ganglion neuron in operated and non-operated animals is showed in Table 2 and Graph 2.

\section{Graph 2 - Number of cell bodies of sensory neurons in the L-5 dorsal root ganglion neuron in the animals studied.}

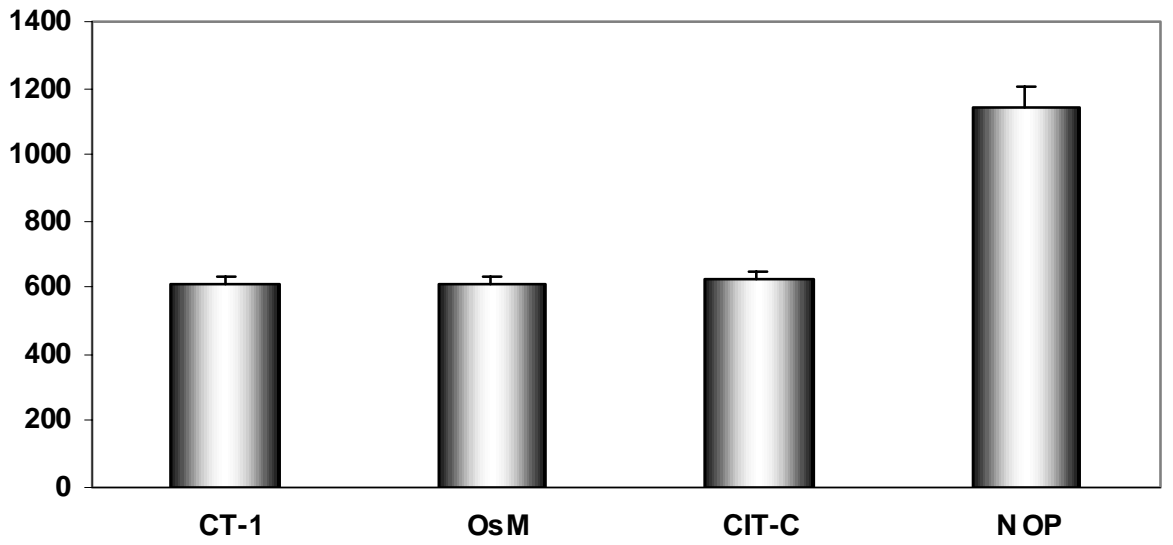

A comparação entre os números de corpos celulares dos 4 grupos de animais, após a análise estatística, demonstrou não haver diferença significativa $(p>0,05)$ entre o grupo de animais implantados com colágeno e CT-1 (634 \pm 29$)$ e colágeno e OsM (694 44$)$, e os que utilizamos colágeno e citocromo-C (657 \pm 18$)$. Os três grupos apresentaram um número de corpos celulares significativamente menor $(p<0,05)$ do que no grupo controle não operado $(1141 \pm 64)$.

ACTA ORTOP BRAS 8(2) - ABR/JUN, 2000
After the statistical analysis, the comparison between the number of cellular bodies of the 4 groups demonstrated no significant difference $(p>0.05)$ between animals implanted with collagen plus CT-1 (634 \pm 29$)$ and collagen plus OsM (694 \pm 4$)$ and collagen plus cytochrome-C (657 \pm 18$)$. The three groups showed a number of cell bodies significantly smaller $(p<0.05)$

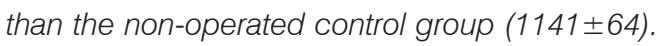




\section{DISCUSSÃO}

As alterações nas porções proximal e distal de um nervo seccionado foram muito estudadas nas últimas décadas.

Vários autores estudaram o brotamento axonal em fibras mielinizadas e a participação dos cones de crescimento neste processo (RAMON Y CAJAL, 1928; HOLMES; YOUNG, 1942; IDE, 1996; MANTHORPE et al., 1983; BIXBY et al. 1988).

As alterações proximais de um nervo periférico seccionado foram chamadas por muitos pesquisadores de "efeito retrógrado" ou "reação axonal", incluindo a cromatólise (NISSL, 1892 apud RAMON Y CAJAL, 1928; GRANT; ALDSKOGIUS, 1967; LIEBERMAN, 1971; SUNDERLAND, 1978; FIORI et al., 1988; KREUTZBERG, 1995). Ao mesmo tempo, observamos que ocorrem mudanças metabólicas que passam a favorecer a produção proteica voltada para a reestruturação celular, em detrimento à transmissão sináptica (LIEBERMAN, 1971; KREUTZBERG, 1995).

A reação de um neurônio à lesão do seu axônio pode variar de uma degeneração retrógrada até a morte celular (RAMON Y CAJAL, 1928; HYDÉN, 1960; LIEBERMAN 1971, 1974; KERR et al., 1972; FAWCETT; KEYNES, 1990; KREUTZBERG, 1995; GROVES, 1997)

Assim como na porção proximal do nervo seccionado, a parte distal também sofre alterações bem definidas. Foi WALLER (1850) apud GREEN (1988) o primeiro a relatar as alterações na porção distal de um nervo seccionado, descrevendo a degeneração granular da bainha de mielina e o desaparecimento dos axônios distais à lesão, ao que denominou-se "degeneração walleriana". (RAMON Y CAJAL, 1928; SUNDERLAND; BRADLEY, 1950).

Vários trabalhos contribuiram para o conhecimento detalhado das alterações na parte distal do nervo lesado. Destacam-se os relatos sobre a ação dos macrófagos, fagocitando a mielina fragmentada e axônios degenerados, promovendo a proliferação das células de Schwann, e produzindo citocinas importantes na regeneração nervosa (HOLMES; YOUNG, 1942; LUBINSKA, 1982; BEUCHE; FRIEDE, 1984; PERRY et al., 1987).

Achamos importante lembrar as descrições de SUNDERLAND (1978) e LUNDBORG (1987) sobre a formação do tubo endoneural, através do qual haverá o crescimento axonal.

Outro elemento indispensável na regeneração nervosa são as células de Schwann, produzidas no coto distal do nervo lesado estimuladas pela membrana axonal, fragmentos de mielina e macrófagos, sendo responsáveis por degradar e fagocitar a mielina e produzir fatores neurotróficos (SATINSKY et al., 1964; SALZER; BUNGE, 1980; HALL, 1986; HEUMANN et al., 1987; FAWCETT; KEYNES, 1990; SENDTNER et al., 1992; DE VRIES, 1993; REYNOLDS; WOOLF, 1993). As células de Schwann alongam-se e conectam-se longitudinalmente formando a imagem semelhante a um colar de pérolas, denominadas como "bandas de Büngner" (SUNDERLAND; BRADLEY, 1950; BUNGE, 1980), servindo como guia para fibras mielínicas e amielínicas alcançarem seus orgãos alvo (SON; THOMPSON, 1995).

\section{DISCUSSION}

Changes in proximal and distal portions of a sectioned nerve have been hardly studied over the last decades.

Several authors studied the axonal sprouting in myelinated fibers and the participation of growth cones in this process (RAMON Y CAJAL, 1928; HOLMES; YOUNG, 1942; you GO, 1996; MANTHORPE et al., 1983; BIXBY et al. 1988).

Many researchers named proximal changes of a sectioned peripheral nerve as "retrograde effect" or "axonal reaction", including the chromatolysis (NISSL, 1892 apud RAMON Y CAJAL, 1928; GRANT; ALDSKOGIUS, 1967; LIEBERMAN, 1971; SUNDERLAND, 1978; FIORI et al., 1988; KREUTZBERG, 1995). Simultaneously, we observed that metabolic changes occurred and favored the proteinic production for cellular restructuring, in detriment to the synaptic transmission (LIEBERMAN, 1971; KREUTZBERG, 1995).

The neuronal reaction to its axonal lesion can vary from a retrograde degeneration up to cellular death (RAMON Y CAJAL, 1928; HYDÉN, 1960; LIEBERMAN 1971, 1974; KERR et al., 1972; FAWCETT; KEYNES, 1990; KREUTZBERG, 1995; GROVES, 1997)

Similarly to the proximal portion of the sectioned nerve, the distal portion also underwent well-defined changes. WALLER (1850) apud GREEN (1988) was the first to report the distal portion changes of a sectioned nerve, describing the granular degeneration of the myelin sheath and the disappearance of axons distally to the lesion, which he named "Wallerian degeneration". (RAMON Y CAJAL, 1928. SUNDERLAND; BRADLEY, 1950).

Several trials have contributed to the best knowledge of the changes in the distal portion of the lesioned nerve. Macrophage phagocytic activity of fragmented myelin and degenerate axons, promoting the proliferation of Schwann cells, and producing important cytokines in nerve regeneration were emphasized (HOLMES; YOUNG, 1942; LUBINSKA, 1982; BEUCHE; FRIEDE, 1984; PERRY et al., 1987).

It is very important to remind SUNDERLAND (1978) and LUNDBORG (1987) reports about the endoneurial tube formation, through which there will be the growth axonal.

Schwann cells produced in the distal stump of the lesioned nerve and stimulated by the axonal membrane, myelin fragments and macrophages is another indispensable element in nerve regeneration. They are responsible for degrading and phagocytozing the myelin and producing neurotrophic factors (SATINSKY et al., 1964; SALZER; BUNGE, 1980; HALL, 1986; HEUMANN et al., 1987; FAWCETT; KEYNES, 1990; SENDTNER et al., 1992; DE VRIES, 1993; REYNOLDS; WOOLF, 1993). Schwann cells are prolonged and connected longitudinally forming an image similar to a pearl necklace, named "bands of Büngner" (SUNDERLAND; BRADLEY, 1950; BUNGE, 1980). They act as guide for myelinated and non-myelinated fibers to reach their target organs (SON; THOMPSON, 1995).

In spite of several researches on changes in the extremities of a peripheral sectioned nerve, the biochemical regulation of this process is not totally cleared.

Several studies reported the difficult nerve regeneration after a peripheral axotomy, characterized by the decrease of the ACTA ORTOP BRAS 8(2) - ABR/JUN, 2000 
Apesar das várias pesquisas sobre as alterações sofridas pelas extremidades de um nervo periférico seccionado, a regulação bioquímica deste processo ainda não foi totalmente esclarecida.

Diversos estudos constataram a dificuldade de regeneração nervosa após uma axotomia periférica, com diminuição do diâmetro da fibra regenerada, formação de uma bainha de mielina mais fina, e consequente diminuição da velocidade de condução (SCHRODER, 1972; FIELDS; ELLISMAN, 1986 a,b).

Embora descrita há muito tempo por RANSON (1909), concordamos com outros autores (ALDSKOGIUS et al., 1992; SUZUKI et al., 1993) que muitas dúvidas sobre a morte celular e suas causas permanecem sem resposta. Nossos achados coincidem com a literatura que, através da contagem de nucléolos de neurônios sensitivos, mostra uma perda celular que pode chegar a 25\% nos gânglios das raizes dorsais Iombares (YGGE; ALDSKOGIUS, 1984; RICH et al., 1989; HIMES; TESSLER, 1989; LISS et al. 1994).

O nosso grande desafio, e das outras pesquisas desenvolvidas nesta área, é estimular o brotamento axonal após uma secção nervosa e, ao mesmo tempo, prevenir a morte celular, obtendo assim uma melhor recuperação funcional, especialmente sensitiva.

Acreditamos haver fortes indícios de que a regeneração sensitiva é pior que a motora (GORDON; STEIN, 1982; SCHMALBRUCH, 1987; LAINETTI et al. 1995; SENDTNER et al., 1997; LJUNGBERG et al., 1999), apesar do trabalho discordante de MADORSKY et al. (1998). A explicação para este fato, é que após uma lesão nervosa periférica, ambos neurônios, motores e sensitivos, ficam privados dos fatores neurotróficos derivados dos orgãos alvo, dos quais depende a sobrevivência da célula nervosa. Porém, os motores produzem de imediato o seu fator específico, o CNTF, a partir das células de Schwann, e assim sobrevivem à lesão axonal (DOBREA et al., 1992). Já os sensitivos são mais suscetíveis à degeneração após a lesão, uma vez que a síntese dos seus fatores neurotróficos, por parte das células de Schwann (NGF e BDNF), é atrasada, não sendo capaz de impedir a morte dos neurônios sensitivos dependentes destes fatores (LAINETTI et al., 1995).

Assim sendo, direcionamos o nosso trabalho para a análise das alterações sofridas pelos neurônios sensitivos após uma secção, tentando através da adição de substâncias exógenas, a CT-1 e a OsM, estimular a regeneração axonal e prevenir a morte neuronal nos gânglios das raízes dorsais.

Concordamos com FUNAKOSHI et al.(1998), quando afirmam que uma das maiores dificuldades no estudo da regeneração nervosa é a necessidade trófica complexa por parte dos neurônios tanto sensitivos quanto motores, dificilmente suprida por um único fator neurotrófico.

Desde o primeiro relato de uma microcirurgia de nervos periféricos (SMITH, 1964), os avanços técnicos e de materiais das últimas décadas vêm possibilitando reparações cada vez menos agressivas aos cotos nervosos. Com esta evolução, aperfeiçoou-se a técnica de tubulização nervosa, escolhida por nós, pois além de pouco traumática, permite o crescimento das fibras nervosas, impede a invasão de tecido cicatricial vizinho, ACTA ORTOP BRAS 8(2) - ABR/JUN, 2000 regenerate fiber diameter, formation of a thinner myelin sheath, and subsequent decrease of the conduction speed (SCHRODER, 1972; FIELDS; ELLISMAN, 1986 a,b).

Although described by RANSON in 1909, we agreed with the authors (ALDSKOGIUS et al., 1992; SUZUKI et al., 1993) who affirm that there are several doubts on cellular death and its causes. Our findings are in accordance with those from the literature i.e., the count of sensory neuron nucleolus shows a cellular loss up to 25\% in lumbar dorsal root ganglions (YGGE; ALDSKOGIUS, 1984; RICH et al., 1989; HIMES; TESSLER, 1989; LISS et al. 1994).

The great challenge is to stimulate the axonal sprouting after a nerve section and prevent cellular death in order to achieve better functional restoration, mainly sensitive.

We believe in the strong indications that sensitive regeneration is worse than motor regeneration (GORDON; STEIN, 1982; SCHMALBRUCH, 1987; LAINETTI et al. 1995; SENDTNER et al., 1997; LJUNGBERG et al., 1999), although MADORSKY et al. (1998) do not agree with this statement. After a peripheral nerve lesion, both motor and sensory neurons are deprived of neurotrophic factors from target organs. The survival of nerve cells depends on these factors. However, motor neurons produce their specific factor CNTF immediately from Schwann cells, and are able to survive in spite of the axonal lesion (DOBREA et al., 1992). Sensory neurons are more susceptible to the degeneration after the lesion, once their synthesis of neurotrophic factors from Schwann cells (NGF and BDNF) is delayed. The death of the sensory neurons, which are dependent from these factors, is inevitable (LAINETTI et al., 1995).

We addressed our trial for analyzing the sensory neuron changes after a section. Through the addition of exogenous substances, CT-1 and OsM, we tried to stimulate the axonal regeneration and avoid the neuronal death in dorsal root ganglions.

We agreed with FUNAKOSHI et al. (1998) that one of the major difficulties in nerve regeneration study are the complex trophic needs from either sensory or motor neurons, which are not supplied by a single neurotrophic factor.

Since the first report about a microsurgery of peripheral nerves (SMITH, 1964), the technical and material advances over the last decades make nerve stump regeneration less aggressive. The entubulation technique has been improved.

We opted for this technique because it is less traumatic. Also, it allows fibers growth, avoids the invasion of cicatricial tissue and facilitates the morphology, biochemistry and physiology study of the micro-environment between nerve stumps after the administration of exogenous substances or interposition of different materials (DA SILVA, 1987; FIELDS et al., 1989; LANGONE, 1991; SAUCER, 1994; LAINETTI, 1995). This can be significant in improving results after peripheral nerve regeneration.

The first references on entubulated nerve lesion come from last century and numberless of subsequent experimental models searched for inert, flexible, and bioabsorbable materials, without causing fibrosis, ischemia, or inflammation and allowing growth factors accumulation (FIELDS et al. 1989).

As many other authors (GARRITY, 1955; DA SILVA; LANGONE, 1989; LANGONE, 1991; MARQUES, 1992; PEAR TREE, 1993, 
e facilita o estudo da morfologia, bioquímica e fisiologia do microambiente entre os cotos nervosos após a administração de substâncias exógenas ou interposição de diferentes materiais (DA SILVA, 1987; FIELDS et al., 1989; LANGONE, 1991; PIRES, 1994; LAINETTI, 1995), o que ao nosso ver pode ser essencial na melhoria dos resultados após reparações de nervos periféricos.

As primeiras referências às lesões nervosas tubulizadas, vêm do século passado e inúmeros modelos experimentais se sucederam, buscando materiais inertes, flexíveis, bioabsorvíveis, que não provocassem fibrose, isquemia, inflamação ou colabassem, permitindo o acúmulo de fatores de crescimento no local (FIELDS et al. 1989).

Assim como outros autores (GARRITY, 1955; DA SILVA; LANGONE, 1989; LANGONE, 1991; MARQUES, 1992; PEREIRA, 1993, 1998), escolhemos os tubos de polietileno, em função da disponibilidade destas próteses em nosso laboratório.

O efeito de substâncias exógenas administradas sobre o local de uma lesão nervosa, ou de materiais colocados entre os cotos nervosos, vêm chamando a atenção de pesquisadores há algum tempo, como elementos facilitadores da regeneração (CHIU et al., 1982; RICH et al., 1987; MADISON et al., 1988; FIELDS et al., 1989; BAILEY et al., 1993; ANSSELIN et al., 1997; FRANCEL et al., 1997; KAKINOKI et al., 1997; MUNSON et al., 1997; DI BENEDETTO, 1998).

Utilizamos em nosso trabalho duas neurocinas, a cardiotrofina-1 (CT-1) e a OsM. Elas se caracterizam por possuirem uma estrutura molecular semelhante, uma unidade receptora comum (gp 130), e serem encontradas em maior quantidade no sistema nervoso periférico que central (MOSLEY et al., 1996). Também fazem parte deste grupo, CNTF, LIF, GPA e as interleucinas 6 e 11 (IL-6/IL11) (HOPKINS; ROTHWELL, 1995). Nos chamou a atenção que em estudos prévios (ADLER et al., 1979; GEARING et al., 1987; YAMAMORI et al., 1989; RICHARDSON, 1994; PEREIRA, 1998; THOMPSON; MAJITHIA, 1998) o CNTF e o LIF estimularam a regeneração nervosa após a sua administração sobre a lesão de nervos ciáticos de camundongos adultos.

Desde a sua identificação (PENNICA et al., 1995), têm-se descrito várias ações da CT-1 sobre o sistema hematopoiético, fígado, rins ou na indução da hipertrofia de miócitos cardíacos in vitro (JIN et al., 1996; PENNICA et al., 1996). Porém, não encontramos nenhuma referência na literatura a respeito de sua ação em lesões de nervos periféricos (SENDTNER et al., 1997). Trabalho recente provou que esta substância está envolvida na regulação da sobrevivência de neurônios sensitivos em ratos recém nascidos, apenas sugerindo que a mesma possa tornarse importante aliada contra a degeneração pós-traumática (HORTON et al., 1998; THIER et al., 1999).

A primeira publicação sobre a OsM deve-se a ZARLING et al. (1986), que a isolaram a partir de uma cultura de células de linfoma histiocítico, caracterizando-se por inibir a divisão de células de melanoma e outras células tumorais humanas. MALIK e colaboradores em 1989, reconheceram a OsM como uma citocina reguladora do crescimento de várias culturas de células de mamíferos.
1998), we chose polyethylene tubes due to their availability in our laboratory.

The effect of exogenous substances administered on the place of a nerve lesion, or materials placed between nerve stumps (like facilitative elements of the regeneration) are attracting researchers' attention. (CHIU et al., 1982; RICH et al., 1987; MADISON et al., 1988; FIELDS et al., 1989; BAILEY et al., 1993; ANSSELIN et al., 1997; FRANCEL et al., 1997; KAKINOKI et al., 1997; MUNSON et al., 1997; DI BENEDETTO, 1998).

In our trial we used two neurokines, cardiotrophin-1 (CT-1) and OsM. They have a similar molecular structure, a common receiving unit (gp 130), and both are found in larger amount in the peripheral nervous system rather than in central nervous system (MOSLEY et al., 1996). CNTF, LIF, GPA and both interleukin-6 and interleukin11 (IL-6/IL-11) are also part of this group (HOPKINS; ROTHWELL, 1995).

Previous studies (ADLER et al., 1979; GEARING et al., 1987; YAMAMORI et al., 1989; RICHARDSON, 1994; PEREIRA, 1998; THOMPSON; MAJITHIA, 1998) demonstrated that CNTF and LIF stimulated nerve regeneration after their administration on lesion of adult mice sciatic nerves.

Since its identification (PENNICA et al., 1995), several actions of CT-1 on the hematopoietic system, liver, kidneys or on the induction of cardiomyocytes hypertrophy in vitro (JIN et al., 1996; PENNICA et al., 1996) have been described. However, there is no reference in the literature regarding its action on lesioned peripheral nerves (SENDTNER et al., 1997). A recent trial proved that this substance is involved in the regulation of sensory neurons survival in newborn mice, which suggest that it can be important against the post-traumatic degeneration (HORTON et al., 1998; THIER et al., 1999).

ZARLING et al. (1986) made the first publication on OsM. They isolated it from cells of a lymphoma histiocytic. In 1989, MALIK and collaborators recognized the OsM as the cytokine that regulates several mammal cellular cultures growth.

We did not find any reference in the literature on the action of CT-1 and OsM in peripheral nerve regeneration process.

Such substances might be produced in "target organs" and liberated through neuronal cells by retrograde pathway, promoting regeneration after an axotomy (PURVES, 1986; PATTERSON; NAWA, 1992; THOMPSON et al., 1997).

We chose C57BL/6J mouse as the experimentation animal, because it is available in our laboratory. Also, it is easy to manipulate, and has low body weight (30 g), which allows lower expense of material. In mice it was demonstrated that, after a peripheral lesion, the nerve regeneration (mainly sensory nerve regeneration) is decreased, which allows study the activity of exogenous substances on the section area of the nerve (LAINETTI et al. 1995).

Only one paw was operated because we observed that animals underwent bilateral denervation have difficulty in locomotion. Proper feeding is limited, which can lead to autophagia of the denervated paw and subsequent infection and death.

Between nerve stumps, a solution of collagen plus CT-1 or OsM was interposed. By contacting the animal body temperature, the ACTA ORTOP BRAS 8(2) - ABR/JUN, 2000 
Não encontramos nenhuma referência na literatura compulsada sobre a ação da CT-1 e da OsM no processo de regeneração nervosa periférica.

Tais substâncias seriam produzidas em "orgãos alvo" e liberadas por via retrógrada, através das células neuronais, promovendo a regeneração após uma axotomia (PURVES, 1986; PATTERSON; NAWA, 1992; THOMPSON et al., 1997).

Escolhemos o camundongo da linhagem C57BL/6J como o animal de experimentação, pois é de fácil manipulação, disponível no laboratório do Instituto de Ciências Biomédicas, e que pelo seu pequeno porte (30g), permite um gasto menor de material. Pesquisas mostraram que nestes animais, após uma lesão periférica, a regeneração das fibras nervosas está diminuída, principalmente das sensitivas, , o que os torna ideais para o estudo do efeito de substâncias exógenas sobre a área de secção do nervo (LAINETTI et al.,1995).

Somente um dos membros foi operado pois observamos previamente, que animais submetidos a denervação bilateral, tem grande dificuldade de locomoção, impedindo-o de alimentar-se adequadamente, o que pode levar a auto-fagia das patas denervadas, com consequente infecção e morte do animal.

Colocamos, entre os cotos nervosos, uma solução de colágeno misturada à CT-1 ou à OsM, líquida às baixas temperaturas, e que se gelifica à temperatura corporal do animal, o que previne o escoamento destas substâncias para fora do tubo. Uma pequena quantidade de vaselina foi colocada na parte proximal do tubo para impedir o extravasamento desta solução enquanto a mesma não se gelifica. O grupo controle recebeu junto com a solução de colágeno, o citocromo-C, substância com mesmo peso molecular das neurotrofinas, porém, sem atividade neurotrófica.

Os camundongos dos nossos grupos, foram colocados por nós em gaiolas individuais e mantidos em ciclo de 12 horas de claro-escuro, durante todo período pós-operatório, evitando assim alterações hormonais que pudessem influenciar o resultado final.

Apesar de estudos discordantes (KIYOTANI et al., 1996; SUZUKI et al, 1999), baseamo-nos em um grande número de trabalhos que estudaram o crescimento axonal através de tubos vazios e que concluiram que a distância de $10 \mathrm{~mm}$ era o limite superior para se obter uma regeneração adequada (BRUNELLI et al., 1994; DEN DUNNEN et al. 1996; FRANCEL et al., 1997). A utilização de substâncias exógenas dentro dos tubos, permitiu a regeneração nervosa em distâncias que chegaram a 25mm (MADISON et al., 1988; BAILEY et al., 1993; ANSSELIN et al., 1997; KAKINOKI et al., 1997; DI BENEDETTO, 1998; $\mathrm{HO}$ et al., 1998), provando que a manipulação do microambiente pode estimular a regeneração. Portanto, nos pareceu adequada a distância de $4 \mathrm{~mm}$ entre os cotos nervosos como nosso padrão, já que trata-se de um espaço que pode ser atravessado com facilidade por axônios em regeneração.

Realizamos a eutanásia após 4 semanas, ao nosso ver, tempo suficiente para que observassemos no pós-operatório, a presença de uma estrutura cilíndrica, vascularizada, unindo o coto proximal ao distal, à qual denominamos de cabo de regeneração (CR). Assim como descrito em outros trabalhos, ACTA ORTOP BRAS 8(2) - ABR/JUN, 2000 extract of collagen becomes a gel, which avoid the leakage of the substances placed inside the tubular prostheses. To avoid the leakage of this preparation, Vaseline was used in the distal extremity of the tube. The control group received collagen plus cytochrome-C, a substance with molecular weight similar to neurotrophin, but without neurotrophic activity.

The mice from our groups were placed in individual cages where 12-hour alternating cycles (clear $x$ darkness) occurred during every postoperative period to avoid hormonal changes that might influence the final result.

In spite of discordance (KIYOTANI et al., 1996; SUZUKI et al, 1999), several trials studied the axonal growth through empty tubes and concluded that $10 \mathrm{~mm}$ was the maximum distance to achieve an appropriate regeneration (BRUNELLI et al., 1994; DEN DUNNEN et al. 1996; FRANCEL et al., 1997). The use of exogenous substances inside the tubes allowed nerve regeneration using distances up to $25 \mathrm{~mm}$ (MADISON et al., 1988; BAILEY et al., 1993; ANSSELIN et al., 1997; KAKINOKI et al., 1997; DI BENEDETTO, 1998; HO et al., 1998). This aspect proved that the manipulation of the microenvironment could stimulate the regeneration. Thus, the 4- $\mathrm{mm}$ distance between nerve stumps seemed adequate as our pattern, since it is a space that can be easily crossed by axons in regeneration.

Euthanasia was performed after 4 weeks postoperatively to observe the presence of a cylindrical vascular structure joining proximal and distal stumps (named for us as regeneration cable - $R C$ ). Between the regeneration cable and the tube wall, a space filled out by a fluid similar to plasma was noted (LUNDBORG et al. 1982; WILLIAMS et al. 1983; DA SILVA, 1987; LANGONE, 1991).

The L-5 dorsal root ganglion was chosen because it is significant for sciatic nerve formation (SWETT et al., 1991).

In the RC and L-5 ganglion histological analysis, we used the methodology described by TOME, MIRA (1981), which consists of fixing the material in glutaraldehyde and osmium tetraoxide $2 \%$, followed by the inclusion in resin Epoxy. Following, sheets are prepared using sections of 2 m of thickness, which are stained using methylene blue, and observed to the microscope.

After 4 weeks from tube implant, all animals underwent surgery exhibited $R C$.

In animals where CT-1 and OsM were used, regeneration cables of larger diameter and larger amount of myelinated axons were observed in relation to groups whose prostheses were filled out with cytochrome-c, showing the role of both substances in the axonal sprouting.

Analyzing the number of sensory neurons in L-5 dorsal root ganglions, we verified that it was statistically lower in the groups where neurokines were used in relation to control groups nonoperated. No significant difference in relation to the group whose tubes were filled out with cytochrome-c was observed. We believed that these results confirm the low efficacy of CT-1 and OsM in sensory neuron survival.

Our expectation from this work is to use the entubulation technique to reduce sutures aggression to nerve stumps, and, simultaneously, to administer exogenous substances to the humane sectioned nerve. This procedure can improve the 
também verificamos entre o cabo de regeneração e a parede do tubo, um espaço preenchido por fluído semelhante ao plasma sanguíneo ( LUNDBORG et al. 1982; WILLIAMS et al. 1983; DASILVA, 1987; LANGONE, 1991).

O gânglio dorsal escolhido por nós foi o da raiz de L5, pois é o que mais contribui na formação do nervo ciático (SWETT et al., 1991).

Na análise histológica dos CR e dos gânglios de L5, utilizamos metodologia descrita por TOME; MIRA (1981), que consiste na fixação do material em glutaraldeído e tetraóxido de ósmio a $2 \%$, seguida de inclusão em resina epoxy. Em seguida as lâminas são preparadas com cortes de $2 \mathrm{~m}$ de espessura, e coradas com azul de metileno, e observadas ao microscópio.

Após 4 semanas do implante do tubo, todos os animais por nós operados apresentavam CR.

Nos animais onde utilizamos a CT-1 e a OsM, observamos cabos de regeneração de maior diâmetro, e com uma quantidade significativamente maior de axônios mielínicos que nos grupos em que as próteses foram preenchidas com citocromo-c, evidenciando o estímulo destas duas substâncias sobre o brotamento axônico.

Analisando o número de neurônios sensitivos nas raízes dorsais de L5, verificamos que nos grupos que utilizaram as neurocinas foi estatisticamente menor que no grupo controle não operado, e sem diferença significativa em relação ao grupo em que os tubos foram preenchidos com citocromo-c. Acreditamos que estes resultados confirmam a baixa eficácia da CT-1 e da OsM na sobrevivência dos neurônios sensitivos.

A nossa expectativa a partir deste trabalho, é que possamos utilizar a tubulização com o objetivo de diminuir a agressão das suturas nos cotos nervosos, e ao mesmo tempo administrar substâncias exógenas no local da reparação do nervo seccionado em seres humanos. Este procedimento poderá melhorar o prognóstico destas lesões e permitir a reparação de perdas segmentares sem a necessidade de enxertos. É provável que o futuro das reparações de nervo perifério basei-se na compreensão dos fenômenos bioquímicos que regulam a sobrevida da célula e o processo de regeneração nervosa. Várias substâncias, como as neurocinas, participam desta regulação. O estudo dos mecanismos fisiológicos é fundamental para o avanço científico desta área. Ao identificar as respostas obtidas com o uso da CT-1 e OsM no tratamento dos nervos periféricos lesados, estamos contribuindo na recuperação de pacientes vítimas deste tipo de lesão.

\section{CONCLUSÕES}

1. A administração local das neurocinas cardiotrofina-1 e oncostatina-M favorece a regeneração nervosa periférica, expressa em número de fibras mielinizadas presentes no cabo de regeneração de nervos ciáticos de camundongos, submetidos a lesão e reconstrução pela técnica de tubulização.

2. A administração de cardiotrofina-1 e oncostatina-M sobre lesões de nervos periféricos, não impede a morte de neurônios sensitivos axotomizados. prognostic of these lesions and allow the repair of losses without using grafts. It is probable that the future of the peripheral nerve repair will depend on the understanding of the biochemical phenomena that regulate the survival of the cell and the process of nerve regeneration. Several substances, as neurokines, participate in this regulation. The study of the physiologic mechanisms is fundamental for the scientific progress in this field. The comprehension of CT-1 and OsM usage in the treatment of lesioned peripheral nerves is contributing to recover patients with this type of lesion.

\section{CONCLUSIONS}

1. The topic administration of cardiotrophin-1 and oncostatin$M$ enhances the peripheral nerve regeneration. This aspect is expressed by the number of myelinated fibers in the cable of regeneration of sciatic nerves of mice underwent lesion and reconstruction by the entubulation technique.

2. The administration of cardiotrophin-1 and oncostatin $-M$ to peripheral nerves does not avoid the death of sensory neurons underwent axotomy.

\section{REFERÊNCIAS}

1) ADLER, R.; LANDA, K.B.; MANTHORPE, M.; VARON, S. Cholinergic neuronotrophic factors: intraocular distribution of trophic activity for ciliary neurons. Science, v. 204, p. 1434-6, 1979.

2) ALDSKOGIUS, H.; ARVIDSSON, J.; GRANT, G. Axotomy-induced changes in primary sensory neurons. Sensory Neurons. Oxford University Press, p. 363-83, New York, 1992.

3) ANSSELIN, A.D.; FINK, T.; DAVEY, D.F. Peripheral nerve regeneration through nerve guides seeded with adult Schwann cells. Neuropathol. Appl. Neurobiol., v. 23, p. 387-98, 1997.

4) BAILEY, S.B.; EICHLER, M.E.; VILLADIEGO, A.; RICH, K.M. The influence of fibronectin and laminin during Schwann cell migration and peripheral nerve regeneration through silicon chambers. J. Neurocytol., v. 22, p. 176-84, 1993.

5) BEUCHE, W.; FRIEDE, R.L. The role of non-resident cells in Wallerian degeneration. J. Neurocytol., v. 13, p. 767-96, 1984.

6) BIXBY, J.L.; LILIEN, J.; REICHARDT, L.F. Identification of the major proteins that promote neuronal process outgrowth on Schwann cells in vitro. J. Cell Biol., v. 107, p. 353-61, 1988.

7) BRUNELLI, G.A.; VIGASIO, A.; BRUNELLI, G.R. Different conduits in peripheral nerve surgery. Microsurgery, v. 15, p. 176-8, 1994.

8) BUNGE, R.P. Some observations on the role of the Schwann cells in peripheral nerve regeneration. In McCARROLL, J. ed. Nerve repair and regeneration - Its clinical and experimental basis. St. Louis, Mosby, 1980. p. 58-64.

9) CHIU, D.T.W.; JANECKA, I.; KRIZEK, T.J. Autogenous vein graft as a conduit for nerve regeneration. Surgery, v. 91, p. 226-33, 1982. ACTA ORTOP BRAS 8(2) - ABR/JUN, 2000 
10) DA SILVA, C.F. Estudo experimental da regeneração de nervos no interior de próteses tubulares. São Paulo, 1987. 58p. Tese (LivreDocência) - Instituto de Ciências Biomédicas, Universidade de São Paulo.

11) DA SILVA, C.F.; LANGONE, F. Addition of nerve growth factor to the interior of a tubular prosthesis increases sensory neuron regeneration in vivo. Braz. J. Med. Biol. Res., v. 22, p. 691-4, 1989.

12) DE VRIES, G.H. Schwann cell proliferation. In: DYCK, P.J.; THOMAS, P.K.; GRIFFIN, J.W.; LOW, P.D.; PODUSLO, J., ed. Peripheral Neuropathy. Philadelphia, W.B. Saunders, 1993. p. 290-8.

13) DEN DUNNEN, W.F.; VAN DER LEI, B.; SCHAKENRAAD, J.M.; STOKROOS, J.; BLAAUW, E.; BARTELS, H.; PENNINGS, A.J.; ROBINSON, P.H. Poly (DL-lactide-epsilon-caprolactone) nerve guides perform better than autologous nerve grafts. Microsurgery, $v$. 17, p. 348-57, 1996.

14) DI BENEDETTO, G.; ZURA, G.; MAZZUCHELLI, R.; SANTINELLI, A.; SCARPELLI, M.; BERTANI, A. Nerve regeneration through a combined autologous conduit (vein plus acellular muscle grafts). Biomaterials, v. 19, p. 173-81, 1998.

15) DOBREA, G.M.; UNNERSTALL, J.R.; RAO, M.S. The expression of CNTF message and immunore-activity in the central and peripheral nervous system of the rat. Devl. Brain Res., v. 66, p. 209-19, 1992.

16) FAWCETT, J.W.; KEYNES, R.J. Peripheral nerve regeneration. Ann.Ver. Neurosci., v. 13, p. 43-60, 1990.

17) FIELDS, R.D.; ELLISMAN, M.H. Axons regenerated through silicone tube splices. I. Conduction properties. Exp. Neurol., v. 92, p. 48-60, 1986a.

18) FIELDS, R.D.; ELLISMAN, M.H. Axons regenerated through silicone tube splices. II. Functional morphology. Exp. Neurol., v. 92, p. 61-74, 1986b.

19) FIELDS, R.D.; LE BEAU, J.M.; LONGO, F.M.; ELLISMAN, M.H. Nerve regeneration *through artificial tubular implants. Prog. Neurobiol., V. 33, p. 87-134, 1989.

20) FIORI, M.G.; DI GREGORIO F.; FABRIS, M.; MARINI, P.; TRIBAN, C.; TOFFANO, G. Processes of peripheral nerve and neuromuscular repair. Ann. Inst. Super. Sanita, v. 24, p. 143-58, 1988.

21) FRANCEL, P.C.; FRANCEL, T.J.; MACKINNON, S.E.; HERTL, C. Enhancing nerve regeneration across a silicone tube conduit by using interposed short-segment nerve grafts. J. Neurosurg., v. 87, p. 88792, 1997.

22) FUNAKOSHI, H.; RISLING, M.; CARLSTEDT, T.; LENDAHL, U.; TIMMUSK, T.; METSIS, M.; YAMAMOTO, Y.; IBAÑEZ, C.F. Targeted expression of a multifunctional chimeric neurotrophin in the lesioned sciatic nerve accelerates regeneration of sensory and motor axons. Proc. Natl. Acad. Sci., v. 95, p. 5269-74, 1998.

23) GARRITY, R.W. The use of plastic and rubber tubing in the management of irreparable nerve injuries. Neurological Surg., v. 6, p. 517-20, 1955.

24) GEARING, D.P.; GOUGH, N.M.; KING, J.A.; HILTON, D.J.; NICOLA, N.A.; SIMPSON, R.J.; NICE, E.C.; KELSO, A.; METCALF, D. Molecular cloning and expression of cDNA encoding a murine myeloid leukaemia inhibitory factor (LIF). EMBO J., v. 6, p. 39954002, 1987.

25) GORDON, T.; STEIN, R.B. Time course and extent of recovery in reinnervated motor units of cat triceps surae muscles. J. Physiol., v.
323, p. 307-23, 1982.

26) GRANT, G.; ALDSKOGIUS, H. Silver impregnation of degenerating dentrites, cells and axons central to axonal transections. A nauta study on the hipoglossal nerve in kittens. Exp. Brain Res., v. 3, p. 150-62, 1967.

27) GROVES, M.J.; CHRISTOPHERSON, T.; GIOMETTO, B.; SCARAVILLI, F. Axotomy-induced apoptosis in adult rat primary sensory neurons. Journal of Neurocytology, v. 26, p. 615-24, 1997.

28) HALL, S.M. Regeneration in cellular and acellular autografts in the peripheral nervous system. Neuropathol. Appl. Neurobiol., v. 12, p. 27-46, 1986.

29) HEUMANN, R.; KORSHING, S.; BANDTLOW, C.; THOENEN, H. Changes of nerve growth factor synthesis in non-neuronal cells in reponse to sciatic nerve transection. J. Cell Biol., v. 104, p. 1623-31, 1987.

30) HIMES, B.T.; TESSLER, A. Death of some dorsal root ganglion neurons and plasticity of others following sciatic nerve section in adult and neonatal rats. J. Comp. Neurol., v. 284, p. 215-30, 1989.

31) HO, P.R.; COAN, G.M.; CHENG, E.T.; NIELL, C.; TARN, D.M.; ZHOU H., SIERRA, D.; TERRIS, D.J. Repair with collagen tubules linked with brain derived neurotrophic factor and ciliary neurotrophic factor in a rat sciatic injury model. Arch. Otolaryngol Head Neck Surg., v. 124, p. 761-6, 1998.

32) HOLMES, W.; YOUNG, J.Z. Nerve regeneration after or immediate delayed suture. J. Anat. (Lond.), v. 77, p. 63-96, 1942.

33) HOPKINS, S.J.; ROTHWELL, N.J. Cytokines and the nervous system I: expression and recognition. TINS, v. 18, p. 83-8, 1995.

34) HORTON, A.R.; BARLETT, P.F.; PENNICA, D.; DAVIES, A.M. Cytokines promote survival of mouse cranial sensory neurones at different developmental stages. Eur. J. Neurosci., v. 10, p. 673-9, 1998.

35) HYDÉN, H. Cell, In: BRACHET, J.; MIRSKY, A.E., ed. New York, Academic Press, 1960. p. 215-323.

36) IDE, C. Peripheral nerve regeneration. Neurosci. Res., v. 25, p. $101-21,1996$

37) JIN, H.; YANG, R.; KELLER, G.A.; RYAN, A.; KO, A.; FINKLE, D. SWANSON, T.A.; LI, W.; PENNICA, D.; WOOD, W.I.; PAONI, N.F. In vivo effects of cardiotrophin-1. Cytokine, v 8, p. 920-6, 1996.

38) KAKINOKI, R.; NISHIJIMA, N.; UEBA, Y.; OKA, M.; YAMAMURO, T.; NAKAMURA, T. Nerve regeneration over a $25 \mathrm{~mm}$ gap in rat sciatic nerves using tubes containing blood vessels: the possibility of clinical application. Int. Orthop., v. 21, p. 332-6, 1997.

39) KERR, J.F.R.; WYLLIE, A.H.; CURRIE, A.R. Apoptosis: a basic biological phenomenon with wide ranging implications in tissue kinetics. British J. of Cancer, v. 26, p. 239-57, 1972.

40) KIYOTANI, T.; TERAMACHI, M.; TAKIMOTO, Y.; NAKAMURA, T.; SHIMIZU, Y.; ENDO, K. Nerve regeneration across a 25-mm gap bridged by a poliglicolic acid-collagen tube: a histological and electrophysiological evaluation of regenerated nerves. Brain Research, v. 740, p. 66-74, 1996.

41) KREUTZBERG, G.W. Reaction of the neuronal cell body to axonal damage. In: WAXMAN, S.G., KOCSIS, J.D. AND STYS, P.K. ed. The Axon: structure, function and pathofisiology. New York, Oxford University Press, 1995. p. 355-74. 
42) LAINETTI, R.D.; PEREIRA, F.C.; DA-SILVA, C.F. Reduced sensory neuron regeneration by C57BL/6J mice. Braz. J. Med. Biol. Res., v. 28, p.781-5, 1995

43) LANGONE, F. Estudo ultra-estrutural e morfométrico de nervos regenerados no interior de próteses tubulares. São Paulo, 1991. 201p (Tese de doutorado - Instituto de Ciências Biomédicas da Univ. de São Paulo).

44) LIEBERMAN, A.R. The axon reaction: a review of the principal features of perikaryal responses to axon injury. Int. Ver. Neurobiol., v. 14, p. 49-124, 1971.

45) LISS, A.G.; EKENSTAM, F.W.; WIBERG, M. Cell loss in sensory ganglia after peripheral nerve injury. An anatomical tracer study using lectin-coupled horseradish peroxidase in cats. Scand. J. Plast. Reconstr. Surg. Hand Surg., v. 28, p. 117-88, 1994.

46) LJUNGBERG, C.; NOVIKOV, L.; KELLERTH, J.O.; EBENDAL, T.; WIBERG, M. The neurotrophins NGF and NT-3 reduce sensory neuronal loss in adult rat after peripheral nerve lesion. Neurosci. Lett., v. 262, p. 29-32, 1999.

47) LUBINSKA, L. Patterns of Wallerian degeneration of myelinated *fibres in short and long peripheral stumps and in isolated segments of rat phrenic nerve. Interpretation of the role of axoplasmic flow of the trophic factor. Brain Res. , v. 233, p. 227-40, 1982.

48) LUNDBORG, G.; GELBERMAN, R.H., LONGO, F.M. In vivo regeneration * of cut nerves encased in silicone tubes. J. Neuropat. Exp. Neurology, v. 41, p. 412-22, 1982.

49) LUNDBORG, G. Nerve regeneration and repair. Acta Orthop. Scand., v. 58, p. 145-69, 1987.

50) MADISON, R.D.; DA SILVA, C.F.; DIKKES, P. Entubulation repair with protein additives increases the maximum nerve gap distance successfully bridged with tubular prostheses. Brain Res., v. 447, p. 325-34, 1988

51) MADORSKY, S.J.; SWETT, J.E.; CRUMLEY, R.L. Motor versus sensory neuron regeneration trough collagen tubules. Plast. Reconstr. Surg., v. 102, p. 430-6, 1998

52) MALIK, N.; KALLESTAD, J.C.; GUNDERSON, N.L.; AUSTIN, S.D.; NEUBAUER, M.G.; OCHS, V.; MARQUARDT, H.; ZARLING, J.M.; SHOYAB, M.; WEI, C.M. Molecular cloning, sequence analysis and functional expression of a novel growth regulator, oncostatin M. Mol. Cell. Biol., v. 9, p. 2847-53, 1989

53) MANTHORPE, M.; ENGVALL, E.; RUOSLAHTI, E.; LONGO, F.M.; DAVIS, G.E.; VARON, S. Laminin promotes neuritic regeneration from cultured peripheral and central neurons. J. Cell Biol., v. 97, p. 1882-90, 1983.

54) MARQUES, M.J. Estudo ultra-estrutural da junção neuromuscular após regeneração nervosa no interior de próteses tubulares. São Paulo, 1992. 140p. Tese (Doutorado) - Instituto de Ciências Biomédicas, Universidade de São Paulo.

55) MOSLEY, B.; DE IMUS, C.; FRIEND, D.; BOIANI, N.; THOMA, B.; PARK, L.S.; COSMAN, D. Dual oncostatin M (OSM) receptors. Cloning and characterization of an alternative signaling subunit conferring OSM-specific receptor activation. J. Biol. Chem., v. 271, p. 32635-43, 1996

56) MUNSON, J.B.; SHELTON, D.L.; MCMAHON, S.B. Adult mammalian sensory and motor neurons: roles of endogenous neurotrophins and rescue by exogenous neurotrophins after axotomy. J. Neurosci., v. 17, n. 1, p. 470-6, 1997.
57) NISSL, F. Uber die veranderungender ganglienzellen am fazialiskern der kaninchen nach ausreissung der nerven. Allg. Z. Psychiat., v. 48, p. 197-8, 1892 apud RAMON Y CAJAL, S. Histology of the nervous system. Oxford University Press, 1928.

58) PATTERSON, P.H.; NAWA, H. Neuronal differentiation factor/ cytokines and synaptic plasticity. Cell, v. 72, p. 123-37, 1992. Supplement.

59) PENNICA, D.; KING, K.L.; SHAW, K.J.; LUIS, E.; RULLAMAS, J.; LUOH, S.M.; DARBONNE, W.C.; KNUTZON, D.S.; YEN, R.; CHIEN, K.R. Expression cloning of cardiotrophin 1 , a cytokine that induces cardiac myocyte hipertrophy. Proc. Natl. Acad. Sci., v. 92, p. 11426, 1995.

60) PENNICA, D.; WOOD, W.I.; CHIEN, K.R. Cardiotrophin-1: a multifunctional cytokine that signals via LIF receptor-gp 130 dependent pathways. Cytokine Growth Factor, v. 1, n. 1, p. 81-91, 1996.

61) PEREIRA, F.C. Estudo experimental e quantitativo da reinervação muscular após regeneração de nervos no interior de próteses tubulares. São Paulo, 1993. 135p. Dissertação (Mestrado) - Instituto de Ciências Biomédicas, Universidade de São Paulo.

62) PEREIRA, F.C. Ações das neurocinas CNTF e IL-6 exógenas na regeneração nervosa periférica. São Paulo, 1998. 79p. Tese (Doutorado) - Instituto de Psicologia, Universidade de São Paulo.

63) PERRY, V.H.; BROWN, M.C.; GORDON, S. The macrophage response to central and peripheral nerve injury. J. Exp. Med., v. 165, p. 1218-23, 1987.

64) PIRES, R.S. Padrão morfométrico de nervos regenerados no interior de próteses tubulares e influência do fator de crescimento nervoso (NGF) exógeno. São Paulo, 1994. P. 171p. Dissertação (Mestrado) - Instituto de Psicologia, Universidade de São Paulo.

65) PURVES, D. The trophic theory of neural connections. Trends in Neurosci., v. 9, p. 486-9, 1986.

66) RAMON Y CAJAL, S. Degeneration and regeneration of the nervous system. London. Oxford. University Press., p. 459, 1928.

67) RANSON, S.W. Alterations in the spinal ganglion cells following neurotomy. J. Comp. Neurol., v. 19, p. 125-53, 1909 apud SCHMALBRUCH, H., 1987, p. 323.

68) REYNOLDS, M.L.; WOOLF, C.J. Reciprocal Schwann cell-axon interaction. Curr. Op. Neurobiol., v. 3, p. 683-93, 1993.

69) RICH, K.M.; LUSZCZYNSKI, J.R.; OSBORNE, P.A.; RICHARDSON, P.M. Nerve growth factor protects adult sensory neurons from cell death and atrophy caused by nerve injury. J. Neurocytol., v. 16, p. 261-8, 1987.

70) RICH, K.M.; DISCH, S.P.; EICHLER, M.E. The influence of regeneration and nerve growth factor on the neuronal cell body reaction to injury. J. Neurocytol., v. 18, p. 569-76, 1989.

71) RICHARDSON, P.M. Ciliary neurotrophic factor: a review. Pharmacol. Ther., v. 63 , p. 187-98, 1994.

72) SALZER, J.L.; BUNGE, R.P. Studies of Schwann cell proliferation. I. An analysis in tissue culture of proliferation during development, Wallerian degeneration, and direct injury. J. Cell. Biol., v. 84, p. 73952, 1980. 
73) SANTOS, X.; RODRIGO, J.; HONTANILLA, B.; BILBAO G. Regeneration of the motor of the rat sciatic nerve with local administration of neurotrophic growth factor in silicone chambers. J. Reconstr. Microsurg., v. 15, p. 207-13, 1999

74) SATINSKY, D.; PEPE, F.A.; LIU, C.N. The neurilemma cell in peripheral nerve degeneration and regeneration. Expl. Neurol., v. 9, p. 441-51, 1964 .

75) SCHMALBRUCH, $\mathrm{H}$. Loss of sensory neurons after sciatic nerve section in the rat. Anat. Rec., v. 219, p. 323-9, 1987.

76) SCHRODER, J.M. Altered ratio between axon diameter and mielyn sheat thickness in regenerated nerve fibers. Brain Res., v. 45, p. 4965, 1972.

77) SENDTNER, M.; GÖTZ, R.; HOLTMANN, B.; THOENEN, H. Endogenous ciliary neurotrophic factor is a lesion factor for axotomized motoneurons in adult mice. J. Neurosci., v. 17, p. 6999-7006, 1997.

78) SENDTNER, M.; STOCKLI, K.A.; THOENEN, H. Synthesis and localization of ciliary neurotrophic factor in the sciatic nerve of the adult rat after lesion and during regeneration. J. Cell Biol., v. 118, p. 139-48, 1992.

79) SMITH, J.W. Microsurgery of peripheral nerves. Plast. Reconst. Surg., v. 33, p. 317-329, 1964.

80) SON, Y.L.; THOMPSON, W.J. Schwann cell processes guide regeneration of peripheral axons. Neuron, v. 14, p. 125-32, 1995.

81) SUNDERLAND, S. Degeneration of the axon and associated changes. In: Ed. S. Sunderland 2 ed. Nerves and nerve injuries. Edinburgh, Churchil Livingstone, 1978. p. 82-107.

82) SUNDERLAND, S.; BRADLEY, K.C. Endoneural tube shrinkage in the distal segment of a severed nerve. J. Comp. Neurol., v. 93, p. 411-20, 1950.

83) SUZUKI, H.; OYANAGI, K.; TAKAHASHI, H.; KONO, M.; YOKOYAMA, M.; IKUTA, F. A quantitative pathological investigation of the cervical cord, roots and ganglia after long-term amputation of the unilateral upper arm. Acta Neuropathol., v. 85, p. 666-73, 1993.

84) SUZUKI, Y.; TANIHARA, M.; OHNISHI, K.; SUZUKI, K.; ENDO, K.; NISHIMURA, Y. Cat peripheral nerve regeneration across $50 \mathrm{~mm}$ gap repaired with a novel nerve guide composed of freeze-dried alginate gel. Neurosci. Lett. v. 259, p. 75-8, 1999.

85) SWETT, J.E.; TORIGOE, Y.; ELIE, V.R.; BOURASSA, C.M.; MILLER, P.G. Sensory neurons of the rat sciatic nerve. Exp. Neurobiol., v. 114, p. 82-103, 1991.

86) THIER, M.; HALL, M.; HEATH, J.K.; PENNICA, D.; WEIS, J. Trophic effects of cardiotrophin-1 and interleukin-11 on rat dorsal root ganglion neurons in vitro. Brain Res. Mol., v. 64, p. 80-4, 1999.

87) THOMPSON, S.W.; MAJITHIA, A.A. Leukemia inhibitory factor induces sympathetic sprouting in intact dorsal root ganglia in the adult rat in vivo. J. Physiol., v. 506 , p. 809-16, 1998.

88) THOMPSON, S.W.; VERNALIS, A.B.; HEATH, J.K.; PRIESTLEY, J.V. Leukaemia inhibitory factor is retrogradely transported by a distinct population of adult rat sensory neurons: co-localization with trkA and other neurochemical markers. Eur. J. Neurosci., v. 9, p. 124451,1997

89) TOME, F.M.S.; MIRA, J.C. Contribution of the morphological technique to the study on peripheral nerve lesions in man and experimental animals. Int. J. Microsurg., v. 3, p. 152-7, 1981.

ACTA ORTOP BRAS 8(2) - ABR/JUN, 2000
90) WALLER, A.V. Experiments on the section of the glossopharyngeal and hypoglossal nerves of the frog, and observations of the alterations produced thereby in the structure of their primitive fibers. Philos. Trans. R. Soc. London, B., v. 140, p. 423-9, 1850 apud GREEN, D.P. Operative Hand Surgery, Churchill Livingstone, 1988, p. 1373.

91) WILLIAMS, L.R.; LONGO, F.M.; POWELL, H.C.; LUNDBORG, G.; VARON, S. Spatial - temporal progress of peripheral nerve regeneration within a silicone chambers: Parameters for a bioassay. J. Comp. Neurol., v. 218, p. 460-70, 1983.

92) YAMAMORI, T.; FUKADA, K.; AEBERSOLD, R.; KORSCHING, S.; FANN, M.J.; PATTERSON, P.H. The cholinergic neuronal differentiation factor from heart cells is identical to leukemia inhibitory factor. Science, v. 15, p. 1412-6, 1989.

93) YGGE, J.; ALDSKOGIUS, H. Intercostal nerve transection and its effect on the dorsal root ganglion. A quantitative study on thoracic ganglion cell numbers and sizes in the rat. Exp. Brain Res., v. 55, p. 402-8, 1984.

94) ZARLING, J.M.; SHOYAB, M.; MARQUARDT, H.; HANSON, M.B.; LIOUBIN, M.N.; TODARO, G.J. Oncostatin M: a growth regulator produced by differentiated histiocytic lymphoma cells. Proc. Natl. Sci., v. 83, p. 9739-43, 1986. 